\title{
Standardised neonatal parenteral nutrition formulations - an Australasian group consensus 2012
}

\author{
Srinivas Bolisetty ${ }^{1,4^{*}}$, David Osborn ${ }^{2,5}$, John Sinn ${ }^{3,5}$, Kei Lui ${ }^{1,4}$ and the Australasian Neonatal Parenteral Nutrition \\ Consensus Group
}

\begin{abstract}
Standardised parenteral nutrition formulations are routinely used in the neonatal intensive care units in Australia and New Zealand. In 2010, a multidisciplinary group was formed to achieve a consensus on the formulations acceptable to majority of the neonatal intensive care units. Literature review was undertaken for each nutrient and recommendations were developed in a series of meetings held between November 2010 and April 2011. Three standard and 2 optional amino acid/dextrose formulations and one lipid emulsion were agreed by majority participants in the consensus. This has a potential to standardise neonatal parenteral nutrition guidelines, reduce costs and prescription errors.
\end{abstract}

Keywords: Parenteral nutrition, Preterm, Neonates, Standardisation

\section{Background}

Parenteral Nutrition (PN) is routinely used in the neonatal intensive care units (NICUs) in Australia and New Zealand (ANZ). The majority use standardised PN formulations. An email survey found there were 61 different neonatal standardised PN formulations compounded and supplied by one pharmaceutical company in October 2009 [1]. This number does not include formulations prepared in-house in some NICUs. In New South Wales (NSW) alone, there were 32 different amino acid/dextrose (AA/Dextrose) formulations.

In November 2010, representatives from various NICUs in the region joined together to form a Neonatal PN Consensus Group. The main objective was to achieve consensus in developing standardised PN formulations agreeable to the majority of the NICUs and to deliver the recommended parenteral nutrient intakes to the majority of the neonatal population in Perinatal NICUs. Standarised PN formulations are safe, stable and compatible

\footnotetext{
* Correspondence: srinivas.bolisetty@sesiahs.health.nsw.gov.au 1 Division of Newborn Services, Royal Hospital for Women, Barker Street, Locked Bag 2000, Randwick, 2031 Sydney NSW, Australia

${ }^{4}$ School of Women's and Children's Heath, University of New South Wales, Sydney, Australia

Full list of author information is available at the end of the article
}

with a long shelf life, are easy and safe to implement so as to avoid errors by rotating frontline staff and are cost effective.

\section{Consensus process}

The group consisted of neonatologists, nursing staff and pharmacists with an input from other experts including a nutritionist and a paediatric gastroenterologist as needed. This group initially consisted of 10 NICUs from the region of New South Wales (NSW) and the Australian Capital Territory (ACT). A series of face-to-face meetings and email correspondence were held between November 2010 and April 2011. A systematic literature search was undertaken and detailed reports were developed for each component of PN. Levels of evidence (LOE) and grades of recommendation (GOR) were allocated according to $\mathrm{Na}-$ tional Health and Medical Research Council (NHMRC) criteria [2]. Where good published evidence was unavailable, recommendations were discussed and, if necessary, voted upon. Members were given plenty of opportunity and time for a thorough literature review, free and open discussion and an exchange of good practice tips among the units. Each member of the group presented the outcomes of the meetings in their individual units and feedback of the comments and suggestions to the consensus 
group for their consideration. Representatives from Baxter Pharmaceuticals Australia were present in some of the meetings and correspondence, but their contribution was limited to advice on the feasibility, stability, compatibility and other pharmaceutical related issues on the formulations recommended by the consensus group. All the writings of the manuscript were in no way influenced by the company. The initial consensus process was completed in June 2011. Subsequently, other tertiary NICUs within Australia, New Zealand, Malaysia, Singapore and India joined the consensus group and contributed to the development of consensus formulations. By April 2013, the consensus group consisted of 22 NICUs from Australasia.

\section{Outcomes}

The Consensus Group addressed the following issues.

\section{Standardised PN versus individualized PN Formulations}

Several observational studies have reported that the use of standardised PN solutions is feasible and appears to offer advantages in some but not all clinical settings [3-7]. Individual studies reported use of standardised PN increased energy and amino acid intake [4-6], calcium and phosphate intake [5,6], reduced early weight loss [4] and reduced costs [6]. The single report of significantly better growth, without added clinical or laboratory complications, from use of a more aggressive nutritional approach including individual $\mathrm{PN}$ is limited by the 5 year time difference between groups and overall changes in nutritional strategies [7]. The consensus Group agreed that standardised PN offers advantages over routine individualised $\mathrm{PN}$ in terms of providing adequate nutrition to the majority of neonates in the NICUs without significant alteration in biochemical responses, with the potential for reduced cost and prescription error (LOE 111-2, GOR C).

\section{Fluid intake}

Systematic review of five studies taken together indicates that restricted water intake significantly increases postnatal weight loss and significantly reduces the risks of patent ductus arteriosus and necrotizing enterocolitis [8]. With restricted water intake, trends were reported toward increased risk of dehydration and reduced risks of bronchopulmonary dysplasia, intracranial haemorrhage, and death, but these trends are not statistically significant. The consensus agreement was new standardised PN should be formulated to provide the Recommended Daily Intakes (RDIs) of nutrients at a total water intake of $150 \mathrm{ml} / \mathrm{kg} /$ day. This includes $135 \mathrm{ml} / \mathrm{kg} /$ day of AA/Dextrose formulation and $15 \mathrm{ml} / \mathrm{kg} /$ day water in the $20 \%$ lipid emulsion. There was general agreement on starting parenteral fluid intake at $60 \mathrm{ml} / \mathrm{kg} /$ day with daily increase by $20-30 \mathrm{ml} / \mathrm{kg} /$ day to an average maximum of $150 \mathrm{ml} / \mathrm{kg} /$ day. However, starting fluid intake can be higher in some VLBW infants due to high water loss in the first few days. In such cases, the PN solutions can still be used to provide the necessary daily intakes of nutrients with extra fluid provided as non-PN solutions (LOE 1, GOR B).

\section{Calorie intake}

Recommended parenteral caloric intake varies from 89 to $120 \mathrm{kcal} / \mathrm{kg} /$ day in preterm neonates [9-11]. Minimal energy requirements are met with $50-60 \mathrm{kcal} / \mathrm{kg} /$ day, but $100-120 \mathrm{kcal} / \mathrm{kg} /$ day facilitate maximal protein accretion [12]. A newborn infant receiving PN needs fewer calories (90-100 kcal/kg/day) than a newborn fed enterally because there is no energy lost in the stools and there is less thermogenesis [13]. Trials of early and/or higher energy intake in preterm infants have reported commencing infants on up to $60 \mathrm{kcal} / \mathrm{kg} /$ day $\mathrm{PN}$ increasing to up to 90-108 $\mathrm{kcal} / \mathrm{kg} /$ day associated with positive nitrogen balance, glucose and biochemical tolerance, and growth [14-16]. The consensus group proposed standardised starter $\mathrm{PN}$ solution at $60 \mathrm{ml} / \mathrm{kg} /$ day and lipid emulsion at $1 \mathrm{~g} / \mathrm{kg} /$ day provides approximately $68 \mathrm{kcal} / \mathrm{kg} /$ day, and the standardised preterm $\mathrm{PN}$ solution at $135 \mathrm{ml} / \mathrm{kg} /$ day and lipid emulsion at $3 \mathrm{~g} / \mathrm{kg} /$ day provides approximately $100 \mathrm{kcal} / \mathrm{kg} /$ day (LOE II, GOR B).

\section{Amino acids}

Trials assessing the efficacy of early (day 1 ) introduction of amino acids have reported higher blood urea nitrogen levels $[17,18]$ and increased nitrogen/protein accretion $[15,17-22]$ and variable effects on glucose tolerance $[15,18,23,24]$. Early use of amino acid solutions may improve glucose tolerance $[15,18,23]$ but may not overcome the effect of a high glucose infusion rate [24]. Limited effects on infant growth have been reported from early introduction of amino acid solutions but no improvements in other neonatal outcomes or long term neurodevelopment reported. A systematic review concluded there is insufficient evidence to guide practice regarding the early versus late administration of amino acids to infants less than 37 weeks gestation [25]. The Consensus Group universally agreed to commence parenteral AA within the first 24 hours of birth (LOE I, GOR C).

Trials assessing the efficacy of higher versus lower early amino acid administration also report higher blood urea nitrogen levels $[14,18,26]$, and increased nitrogen/ protein accretion [18,27]. Rates of early amino acid intake ranged from $0.5 \mathrm{~g} / \mathrm{kg} /$ day to $3.5 \mathrm{~g} / \mathrm{kg} /$ day. The majority of studies did not report any significant differences in initial weight loss or subsequent growth $[14,16,18,28]$. A single study reported reduced weight loss but increased use of insulin for glucose intolerance from early 
amino acid and lipid intakes of $2 \mathrm{~g} / \mathrm{kg} /$ day of each compared to $1 \mathrm{~g} / \mathrm{kg} /$ day [16]. Data suggest biochemical tolerance and improved nitrogen/protein balance commencing with $2-2.4 \mathrm{~g} / \mathrm{kg} /$ day amino acid $[16,18,26]$ with limited data reporting the biochemical safety at 3.0-3.5 g/ $/ \mathrm{kg} /$ day $[15,27]$. No improvements in other neonatal outcomes or long term neurodevelopment reported. The Consensus Group agreed to commence parenteral AA at $2 \mathrm{~g} / \mathrm{kg} /$ day (LOE II, GOR C).

Trials assessing the efficacy of higher maximal rates of amino acid administration have assessed the effects of up to $3.5-4 \mathrm{~g} / \mathrm{kg} /$ day $[14,15,26]$. Higher rates of maximal amino acid administration were associated with higher blood urea nitrogen levels [14,26] and increased nitrogen/protein accretion [15]. No significant difference in growth has been reported although this may reflect enteral nutrition practices. Blanco et al. studied the effect of a high parenteral amino acid intake $2 \mathrm{~g} / \mathrm{kg} / \mathrm{d}$ at birth to a max $4 \mathrm{~g} / \mathrm{kg} / \mathrm{d}$ by day 3 in 30 infants born $<1000 \mathrm{~g}$ and reported biochemical intolerance resulting in discontinuation of intervention in 6 extremely premature infants with peak blood urea nitrogen $>21 \mathrm{mmol} / \mathrm{L}$ (60 mg/dl) and plasma ammonia level >97 $\mu \mathrm{mol} / \mathrm{L}$ [26]. The peak blood urea nitrogen levels were well above normative data [29] although metabolic acidosis was not observed and plasma ammonia levels up to $123 \mu \mathrm{mol} / \mathrm{L}$ may be normal in extremely low birth weight infants [30]. The Consensus Group agreed to incrementally increase amino acid infusions to a maximum $4 \mathrm{~g} / \mathrm{kg} /$ day over 3-5 days (LOE II, GOR C).

\section{Carbohydrates}

ESPGHAN recommend the rate of glucose infusion should not exceed the maximum rate of glucose oxidation as excessive glucose intake may be responsible for hyperglycaemia [31]. Maximal glucose oxidation has been reported in preterm infants to be $8.3 \mathrm{mg} / \mathrm{kg}$ per $\min (12 \mathrm{~g} / \mathrm{kg}$ per day) [32,33], and in term infants $13 \mathrm{mg} / \mathrm{kg}$ per $\mathrm{min}(18 \mathrm{~g} / \mathrm{kg}$ per day) [34,35]. Elevated neonatal blood glucose concentration has been linked to adverse outcomes including death [36,37], intraventricular haemorrhage [36], late onset bacterial infection [38], fungal infection $[39,40]$, retinopathy of prematurity [41-43] and necrotizing enterocolitis [38]. Attempts to maintain glucose intake using insulin have yielded variable results $[44,45]$. For prevention of hyperglycaemia, a systematic review found two small trials which compared lower versus higher glucose infusion rates [45]. These trials provided some evidence that a lower glucose infusion rate reduced mean blood glucose concentrations and the risk of hyperglycaemia, but had insufficient power to test for significant effects on death or major morbidities $[16,46]$. The trials had glucose infusion rates up to $8.4 \mathrm{mg} / \mathrm{kg} / \mathrm{min}$ in the first 7 days in the highest infusion group. In contrast, the multicentre trial of insulin infusion reported that although insulin infusion reduced mean glucose concentrations and reduced hyperglycaemia, it resulted in an increase in the risk of death before 28 days and an increase in the proportion of neonates with a hypoglycaemic episode [47]. Glucose infusion rates were higher in the insulin group compared to the standard care group (median 9.3 versus $7.6 \mathrm{mg} / \mathrm{kg} / \mathrm{min}$ ). The review concluded the evidence does not support the routine use of insulin infusions to prevent hyperglycaemia in VLBW neonates. A second systematic review found two trials that compared use of insulin infusion for treatment of hyperglycaemia [44]. Collins 1991 reported that infants treated with insulin infusion received significantly higher glucose infusion rates than infants treated with no glucose reduction $(20.1 \pm 2.5$ versus $13.2 \pm 3.2 \mathrm{mg} / \mathrm{kg} / \mathrm{min}$ ), and significant increases in nonprotein energy intake and short-term weight gain [48]. Meetze 1998 reported glucose infusion rate averaged approximately $10.0 \mathrm{mg} / \mathrm{kg} / \mathrm{min}$ in the insulin infusion group and approximately $7.6 \mathrm{mg} / \mathrm{kg} / \mathrm{min}$ in the glucose reduction group, and significant increase in total energy intake [49]. Neither reported a significant difference in neonatal mortality or morbidity.

Proposed standard preterm and term PN formulations contain $10 \%$ and $12 \%$ dextrose respectively, providing $13.5(9.4 \mathrm{mg} / \mathrm{kg} / \mathrm{min})$ and $17 \mathrm{~g} / \mathrm{kg} /$ day $(11.8 \mathrm{mg} / \mathrm{kg} / \mathrm{min})$ at $135 \mathrm{ml} / \mathrm{kg} /$ day respectively (LOE 1, GOR C).

\section{Sodium, Potassium and Chloride}

Higher early sodium intake may be associated with early hypernatraemia and increased oxygen requirements to 28 days [50-53]. There is insufficient evidence to determine an effect on other neonatal outcomes and mortality [50,51]. Subsequent higher sodium intake may reduce the incidence of hyponatraemia [50-52,54]. The consensus group agreed on minimal sodium intake approximately $1 \mathrm{mmol} / \mathrm{kg} / \mathrm{d}$ on day 1 using a starter PN formulation, with an increase to a maximum $4.5 \mathrm{mmol} /$ $\mathrm{kg} / \mathrm{d}$ in preterm and $3.5 \mathrm{mmol} / \mathrm{kg} /$ day in term infants (LOE II, GOR C).

Hyperkalaemia is a common complication in the first 48 hours of life in very low birth weight and/or very preterm [55]. In a clinical trial, it was not affected by early and high administration of protein [26]. After 3 days, balance studies reported a potassium intake of 2$3 \mathrm{mmol} / \mathrm{L} /$ day resulted in a net retention of $1-2 \mathrm{mmol} /$ day $[56,57]$. The consensus group agreed on minimal potassium intake using starter $\mathrm{PN}$ formulation, with an increase in standard formulations to a maximum $3.0 \mathrm{mmol} / \mathrm{kg} / \mathrm{d}$ in preterm and $3.5 \mathrm{mmol} / \mathrm{kg} /$ day in term infants (LOE III-2, GOR C).

Hyperchloraemia ( $>115 \mathrm{mmol} / \mathrm{L}$ ) is a common problem in VLBW infants on PN and is associated with 
acidosis [58,59]. Trial evidence found the incidence of hyperchloraemia and acidosis is reduced by partly replacing chloride with acetate in parenteral nutrition [58]. Consensus was to adopt the trial recommendation of the first $3 \mathrm{mmol} / \mathrm{kg} /$ day of anion to be provided as chloride, next $6 \mathrm{mmol} / \mathrm{kg} /$ day of anion to be provided as acetate and thereafter as chloride again. Supplementation of acetate beyond this level was associated with hypercarbia [58] (LOE II, GOR C).

\section{Calcium, Phosphate and Magnesium}

The range of recommended doses of $\mathrm{Ca}$ and $\mathrm{P}$ delivered by $\mathrm{PN}$ in preterm infants is wide, varying from 1.3$3 \mathrm{mmol} \mathrm{Ca} / \mathrm{kg} /$ day and $1.0-2.3 \mathrm{mmol} \mathrm{P} / \mathrm{kg} /$ day, with a $\mathrm{Ca}: \mathrm{P}$ ratio in the range of 1.3-1.7 [9,10]. Lower doses may be inadequate for some infants, compromising short and long-term bone formation. Trials have reported higher intakes of calcium and phosphate increase mineral retention, bone mineral content and bone strength $[60,61]$. However, the threshold for calciumphosphate precipitation limits the delivery of appropriate amounts of $\mathrm{Ca}$ and P by PN [62]. Substitution of inorganic phosphate by organic phosphate improves physicochemical compatibility which trial evidence reported allowed for increased mineral intake and mineral retention [63]. However, there is no registered organic phosphate in Australia. The consensus formulations are not to exceed $12 \mathrm{mmol} / \mathrm{L}$ of calcium and $10 \mathrm{mmol} / \mathrm{L}$ of inorganic phosphorus due to concerns about physicochemical compatibility and precipitates (LOE II, GOR C).

Balance studies indicate that a magnesium intake $0.375 \mathrm{mmol} / \mathrm{kg} /$ day may result in elevated serum magnesium levels without clinical evidence of hypomagnesaemia, and for $\mathrm{Mg}$ intake a minimum of $0.2 \mathrm{mmol} / \mathrm{kg} /$ day and $0.3 \mathrm{mmol} / \mathrm{kg} /$ day would be appropriate for LBW infants [64,65] (LOE 111-3, GOR C).

\section{Heparin}

Systematic review of prophylactic use of heparin for peripherally placed percutaneous central venous catheters found a reduced risk of catheter occlusion with no statistically significant difference in the duration of catheter patency, risk of thrombosis, catheter related sepsis or extension of intraventricular haemorrhage [66]. Heparin was added at 0.5 to $1 \mathrm{IU} / \mathrm{ml}$ to parenteral nutrition solution with no adverse effect reported. The consensus formulations contain heparin $0.5 \mathrm{IU} / \mathrm{ml}$ (LOE I, GOR C).

\section{Consensus AA/dextrose formulations}

Based on the above principles, the Consensus Group agreed on 3 standard and 3 optional standardised AA/ Dextrose formulations (Table 1). Three Standard formulations are as follows:
(1) Starter PN - suitable for both term and preterm neonates in the first $1-2$ days. It contains $33 \mathrm{~g} / \mathrm{L}$ of amino acids (AA 3.3\%) and 10\% dextrose. It provides $2 \mathrm{~g} / \mathrm{kg} /$ day of amino acids at $60 \mathrm{ml} / \mathrm{kg} /$ day. It contains minimum $\mathrm{Na}(15 \mathrm{mmol} / \mathrm{L})$ and no potassium. This formulation may be used up to $120 \mathrm{ml} / \mathrm{kg} /$ day for occasional infants on fluid restriction and renal impairment. At $90 \mathrm{ml} / \mathrm{kg} /$ day this solution provides $3 \mathrm{~g} / \mathrm{kg} /$ day amino acids beyond which the recommended protein intake is exceeded for term infants [10]. At $120 \mathrm{ml} / \mathrm{kg} /$ day the solution provides $4 \mathrm{~g} / \mathrm{kg} /$ day of amino acids beyond which the recommended preterm intake is exceeded [10].

(2) Standard Preterm PN - This is suitable for stable preterm infants after the first 24 hours. It provides $4 \mathrm{~g} / \mathrm{kg} /$ day of amino acids and $12 \mathrm{~g} / \mathrm{kg} /$ day of glucose at $135 \mathrm{ml} / \mathrm{kg} /$ day.

(3) Standard Term PN - Suitable for stable term neonates after the first 24 hours of life. It provides $3 \mathrm{~g} / \mathrm{kg} /$ day of amino acid and $18 \mathrm{~g} / \mathrm{kg} /$ day of glucose at $135 \mathrm{ml} / \mathrm{kg} /$ day.

Two optional AA/Dextrose solutions have also been agreed upon by majority units to provide the $\mathrm{PN}$ for preterm infants with hyponatraemia and hyperglycaemia.

(1) High Sodium Preterm PN - similar to standard preterm PN with higher $\mathrm{Na}$ content $(60 \mathrm{mmol} / \mathrm{L})$ provides $\mathrm{Na} 8 \mathrm{mmol} / \mathrm{kg} /$ day at $135 \mathrm{ml} / \mathrm{kg} /$ day along with increased chloride and acetate.

(2) 7.5\% Dextrose Preterm PN - similar to standard preterm TPN with the exception of $7.5 \%$ dextrose providing $10 \mathrm{~g} / \mathrm{kg} /$ day glucose at $135 \mathrm{ml} / \mathrm{kg} /$ day.

\section{Lipids}

Administration of lipid in premature infants requiring PN provides essential fatty acids and increases caloric intake with a low volume [10]. Two systematic reviews found that although no side effects were reported there was no statistically significant benefit of introducing lipids before two to five days of age, including no beneficial effects on growth $[67,68]$. However, essential fatty acid deficiency occurs rapidly and can be prevented with introduction of as little as 0.5 to $1 \mathrm{~g} / \mathrm{kg} /$ day of lipid infusion [67]. The Consensus agreed timing of commencement of parenteral lipid will be determined by individual NICUs with day 1 administration as an option (LOE 1 , GOR C).

Several types of intravenous lipid emulsions (IVLE) are available for neonatal use including $100 \%$ soybean oil based IVLEs (e.g. Intralipid 20\%, Ivelip 20\%); mixed 80\% olive oil/20\% soybean oil IVLE (e.g. Clinoleic 20\%); mixed $30 \%$ soybean oil $/ 25 \%$ olive oil $/ 30 \%$ medium-chain 
Table 1 Consensus AA/dextrose formulations

\begin{tabular}{|c|c|c|c|c|c|}
\hline & Starter PN & Standard preterm PN & High sodium preterm PN & 7.5\% dextrose preterm PN & Term PN \\
\hline \multicolumn{6}{|l|}{ Conc/Litre } \\
\hline$A A, g$ & 33 & 30 & 30 & 30 & 23 \\
\hline Glucose, g & 100 & 100 & 100 & 75 & 120 \\
\hline $\mathrm{Na}, \mathrm{mmol}$ & 15 & 33 & 60 & 33 & 25 \\
\hline $\mathrm{K}, \mathrm{mmol}$ & 0 & 22 & 22 & 22 & 20 \\
\hline $\mathrm{Cl}, \mathrm{mmol}$ & 12 & 16 & 36 & 22 & 26 \\
\hline $\mathrm{Ca}, \mathrm{mmol}$ & 12 & 12 & 12 & 12 & 12 \\
\hline Mg, mmol & 1.5 & 1.5 & 1.5 & 1.5 & 1.5 \\
\hline $\mathrm{Ph}, \mathrm{mmol}$ & 10 & 10 & 10 & 10 & 10 \\
\hline Acetate, mmol & 5 & 40 & 44 & 40 & 13.5 \\
\hline Zinc, $\mu \mathrm{g}$ & 0 & 3260 & 3260 & 3260 & 1900 \\
\hline Selenium, $\mu \mathrm{g}$ & 0 & 20 & 20 & 20 & 20 \\
\hline lodine, $\mu \mathrm{g}$ & 0 & 8 & 8 & 8 & 8 \\
\hline Heparin, units & 500 & 500 & 500 & 500 & 500 \\
\hline Osmol, mosm/L & 813 & 790 & 790 & 651 & 847 \\
\hline \multicolumn{6}{|l|}{ At $135 \mathrm{ml} / \mathrm{kg} /$ Day } \\
\hline Energy, Kcal/kg/day† & 72 & 70 & 70 & 57 & 77 \\
\hline AA, g/kg/day & 4.5 & 4 & 4 & 4 & 3 \\
\hline Glucose, g/kg/day & 13.5 & 13.5 & 13.5 & 10 & 16.2 \\
\hline $\mathrm{Na}, \mathrm{mmol} / \mathrm{kg} /$ day & 2 & 4.5 & 8.1 & 4.5 & 3.4 \\
\hline $\mathrm{K}, \mathrm{mmol} / \mathrm{kg} / \mathrm{day}$ & 0 & 3 & 3 & 3 & 2.7 \\
\hline $\mathrm{Cl}, \mathrm{mmol} / \mathrm{kg} /$ day & 1.6 & 2.2 & 4.9 & 3 & 3.5 \\
\hline Acetate $\mathrm{mmol} / \mathrm{kg} /$ day & 0.7 & 5.4 & 6 & 5.4 & 1.8 \\
\hline $\mathrm{Ca}, \mathrm{mmol} / \mathrm{kg} /$ day & 1.6 & 1.6 & 1.6 & 1.6 & 1.6 \\
\hline $\mathrm{Ph}, \mathrm{mmol} / \mathrm{kg} /$ day & 1.4 & 1.4 & 1.4 & 1.4 & 1.4 \\
\hline $\mathrm{Mg}, \mathrm{mmol} / \mathrm{kg} /$ day & 0.2 & 0.2 & 0.2 & 0.2 & 0.2 \\
\hline Zinc, $\mu \mathrm{g} / \mathrm{kg} /$ day & 0 & 440 & 440 & 440 & 256 \\
\hline Selenium, $\mu \mathrm{g} / \mathrm{kg} /$ day & 0 & 2.7 & 2.7 & 2.7 & 2.7 \\
\hline lodine, $\mu \mathrm{g} / \mathrm{kg} /$ day & 0 & 1 & 1 & 1 & 1 \\
\hline
\end{tabular}

tEnergy rates are based on estimated $4 \mathrm{kcal}$ per each gram of glucose and protein.

triglyceride oil/15\% fish oil IVLE (e.g. SMOFlipid); and $100 \%$ fish oil based IVLE (e.g. Omegaven). The IVLEs are largely well tolerated. No reproducible clinical benefits have been reported for any specific IVLE in newborn infants [69-80]. Although reduced peroxide formation [81] and some biochemical difference in infants have been reported [78], a reduced incidence of cholestasis has not been reported using any specific preparation in newborns to date. After consideration of costs, the consensus group agreed to continue with the current practice of olive oil based emulsion in the majority of NICUs (LOE II, GOR C).

The current Consensus emulsion contains 20\% lipid and $80 \%$ water (Clinoleic 20\%). In view of benefits in neonatal morbidities reported in a systematic review [8], the group proposed to include lipids in the total fluid intake, which equates to $15 \mathrm{ml} / \mathrm{kg} / \mathrm{d}$ of water when the lipid intake reaches $3 \mathrm{~g} / \mathrm{kg} /$ day (LOE I, GOR B). The proposed lipid emulsion with the vitamins are available in 2 volumes: $50 \mathrm{ml}$ opaque syringes and $150 \mathrm{ml}$ bags. Each $50 \mathrm{ml}$ contains the following: Clinoleic 20\% $36 \mathrm{ml}$, Vitalipid 10\% - $11.2 \mathrm{ml}$ and Soluvit reconstituted in water for injection $-2.8 \mathrm{ml}$.

\section{Vitamins}

Water and fat soluble vitamins (Soluvit and Vitalipid $10 \%)$ are added to the lipid emulsion to increase the vitamin stability [82]. Table 2 shows the amount of vitamins supplied to infants through the proposed lipid emulsion when run at $3 \mathrm{~g} / \mathrm{kg} /$ day. The doses of vitamin $\mathrm{K}$, pyridoxine and riboflavin are above recommended parenteral doses, and ascorbate below $[9,10]$. Loss of 
Table 2 Parenteral RDIs of vitamins and the comparison to the consensus formulations

\begin{tabular}{lll}
\hline Element & Parenteral RDIs十 & $\begin{array}{l}\text { Lipid emulsion @ } \\
\mathbf{3 ~ g / k g / d a y}\end{array}$ \\
\hline Vit A, IU/kg/day & $700-1500$ & 920 \\
Vit D, IU/kg/day & $40-160$ & 160 \\
Vit E, IU/kg/day & $2.8-3.5$ & 2.8 \\
Vit K, $\mu \mathrm{g} / \mathrm{kg} /$ day & 10 & 80 \\
Ascorbate, mg/kg/day & $15-25$ & 10 \\
Thiamine, $\mu \mathrm{g} / \mathrm{kg} /$ day & $200-500$ & 310 \\
Riboflavine, $\mu \mathrm{g} / \mathrm{kg} /$ day & $150-200$ & 360 \\
Pyridoxine, $\mu \mathrm{g} / \mathrm{kg} /$ day & $150-200$ & 400 \\
Nicotinamide, mg/kg/day & $4-6.8$ & 4 \\
Pantothenate, mg/kg/day & $1-2$ & 1.5 \\
Biotin, $\mu \mathrm{gg} / \mathrm{kg} /$ day & $5-8$ & 6 \\
Folate, $\mu \mathrm{g} / \mathrm{kg} /$ day & 56 & 40 \\
Vit B12, $\mu \mathrm{gg} / \mathrm{kg} /$ day & 0.3 & 0.5 \\
\hline
\end{tabular}

tRDIs adapted from AAP 2009 and ESPGHAN2005 recommendations.

vitamins and formation of peroxides from exposure to light is substantially reduced by adding the preparation to the lipid infusate, covering and use of amber/dark syringes and tubing [83-85] (LOE II, GOR B).

Optimal doses and conditions of infusion for vitamins in infants and children have not been established [10]. The doses of many vitamins (eg Thiamine, Riboflavin, Folate, Vitamin B12, Pyridoxine, and Vitamin C) are largely determined by studies determining vitamin levels during intravenous supply undertaken with commercially available mixtures $[10,86-88]$.

Vitamin A: Systematic review found that supplementation of very low birthweight infants with vitamin A is associated with reduction in death or oxygen use at one month of age and oxygen use at 36 weeks' postmenstrual age, but this needs to be balanced against the lack of other proven benefits and the acceptability of treatment [89]. Current dosing recommendations for parenteral vitamin A supplementation for premature infants are based on clinical studies measuring vitamin levels during supplementation [10] (LOE I GOR C).

Vitamin C: A single randomised trial reported no significant benefits or harmful effects were associated with treatment allocation to higher or lower ascorbic acid supplementation throughout the first 28 days [90]. The lower group received $10 \mathrm{mg}$ parenterally provided in Soluvit and Vitalipid (LOE II, GOR C).

Vitamin D: The consensus formulation delivers vitamin D $160 \mathrm{IU} / \mathrm{kg} /$ day, above the minimal required vitamin D intake reported to maintain $25(\mathrm{OH})$ vitamin $\mathrm{D}$ levels [64] and consistent with studies reporting stable vitamin $\mathrm{D}$ status in preterm infants on $\mathrm{PN}$ [91] (LOE III-3, GOR C).
Vitamin E: Systematic review found Vitamin E supplementation in preterm infants reduced the risk of intracranial hemorrhage but increased the risk of sepsis. It concluded evidence does not support the routine use of vitamin E supplementation by intravenous route at high doses or aiming at serum tocopherol levels greater than $3.5 \mathrm{mg} / \mathrm{dL}$, supporting the current recommendation for parenteral intake of vitamin E [92] (LOE I, GOR B).

Vitamin K: Preterm infants who received intramuscular Vitamin K $1 \mathrm{mg}$ at birth, followed by parenteral intake $(60 \mu \mathrm{g} /$ day for infants $<1000 \mathrm{~g}$ and $130 \mu \mathrm{g} /$ day for infants 1000 to $3000 \mathrm{~g}$ ) had much higher vitamin $\mathrm{K}$ plasma concentrations at 2 and 6 weeks of age than previously reported in healthy, term, formula-fed infants (4-6 $\mathrm{ng} / \mathrm{mL}$ ) [93]. The only formulation available in Australia delivers in excess of current recommendation [10] and is associated with high vitamin $\mathrm{K}$ plasma concentrations (LOE 111-3, GOR C).

\section{Trace elements}

Chromium, copper, iodine, manganese, molybdenum, selenium and zinc are essential micronutrients involved in many metabolic processes. Table 3 shows the parenteral RDIs of trace elements (EPSGHAN) [10] and the comparison to the consensus group formulations. Nutritional deficiency in low birth weight or preterm infants on parenteral nutrition has been mostly reported for zinc and copper [94]. The risk is substantially increased in surgical infants with increased gastrointestinal losses. There are no reports of clinical manganese deficiency in newborns on PN [94]. Copper and manganese may need to be withheld if the neonate develops $\mathrm{PN}$-associated liver disease. Copper has the potential for hepatotoxicity and biliary excretion is important for manganese which is potentially neurotoxic [94]. Low blood selenium

Table 3 Parenteral RDIs of trace elements and the comparison to the consensus formulations

\begin{tabular}{lll}
\hline Element & Parenteral RDIst & $\begin{array}{l}\text { PN solution@ } \\
\mathbf{1 3 5} \mathbf{~ m l} / \mathbf{k g} / \text { day }\end{array}$ \\
\hline Zinc, $\mu \mathrm{g} / \mathrm{kg} / \mathrm{day}$ & $450-500$ (preterm) & 440 (preterm) \\
& 250 (term) & 256 (term) \\
Selenium, $\mu \mathrm{g} / \mathrm{kg} /$ day & $2-3$ & 2.7 \\
lodine, $\mu \mathrm{g} / \mathrm{kg} / \mathrm{day}$ & 1 & 1 \\
Chromium, $\mu \mathrm{g} / \mathrm{kg} /$ day & 0 & 0 (may 'contaminate') \\
Copper, $\mu \mathrm{g} / \mathrm{kg} / \mathrm{day}$ & 20 & 0 initial \\
& & $20^{*}$ \\
Manganese $\mu \mathrm{g} / \mathrm{kg} /$ day & 1 & 0 initial \\
& & $1^{*}$ \\
Molybdenum $\mu \mathrm{gg} / \mathrm{kg} /$ day & 1 & 0 initial \\
& & $1^{*}$ \\
\hline
\end{tabular}

†RDIs adapted from ESPGHAN2005 recommendations. *Consensus recommendation to add if more than 2 to 4 weeks PN. 
concentrations in preterm infants have been reported as a potential risk factor for chronic neonatal lung disease and retinopathy of prematurity [95]. Iodine deficiency and excess have been reported in preterm infants, with iodine excess associated with transient hypothyroidism [96-98]. There have been few reports of chromium deficiency in humans [94]. PN solutions may be contaminated with chromium, causing serum concentrations to be significantly higher (10\%-100\%) than recommended [99]. There is a concern excess chromium intake may be associated with renal impairment in preterm infants [100].

Zinc: Zinc doses are derived from clinical trials reporting zinc levels and zinc balance in preterm and term infants [101-103]. Clinical benefits from different parenteral intake have not been reported in trials. Parenteral zinc is recommended at a dose of $450-500 \mu \mathrm{g} / \mathrm{kg} /$ day for premature infants and $250 \mu \mathrm{g} / \mathrm{kg} /$ day for infants less than 3 months [10]. Zinc is recommended to be added to solutions of patients on short-term PN from commencement [10,94] (LOE II. GOR C).

Copper: Copper doses are derived from clinical trials reporting copper levels and copper balance in preterm and term infants [101-103]. Clinical benefits from different parenteral intake have not been reported in trials. Parenteral copper intake is recommended at a dose of $20 \mu \mathrm{g} / \mathrm{kg} /$ day [10], and commenced 2 to 4 weeks after PN commencement [94]. Copper should be carefully monitored in patients with cholestatic liver disease $[10,94]$ (LOE II, GOR C).

Selenium: Systematic review found supplementing very preterm infants with selenium is associated with a reduction in episodes of sepsis, but was not associated with improved survival, a reduction in neonatal chronic lung disease or retinopathy of prematurity. Doses of $3 \mu \mathrm{g} / \mathrm{kg} / \mathrm{d}$ may prevent a decline in cord levels and doses up to $7 \mu \mathrm{g}$ may be required to achieve concentrations above those in cords and close to concentrations found in healthy breast fed infants [95]. Selenium supply of 2 to $3 \mu \mathrm{g} / \mathrm{kg} /$ day is currently recommended for parenterally fed LBW infants [10] (LOE I, GOR C).

Iodine: Observation data suggest preterm infants receiving PN containing a mean iodine intake of $3 \mu \mathrm{g} / \mathrm{kg} /$ day are in negative iodine balance [97]. However, the relationship to transient thyroid dysfunction in preterm infants is unclear. Enterally fed infants are recommended to receive iodine $11-55 \mu \mathrm{g} / \mathrm{kg} /$ day [104], although a small trial reported no evidence of an effect of higher enteral iodine intake on thyroid hormone levels in very preterm infants [105]. Iodine intake needs to be appraised in the context of iodine status and iodine exposures of pregnant women and their infants. The recommended parenteral intake is currently $1 \mu \mathrm{g} / \mathrm{kg} /$ day [10] (LOE III-3, GOR D).

Manganese: A randomised trial comparing $\mathrm{PN}$ intake of $1 \mu \mathrm{mol} / \mathrm{kg} /$ day versus $0.0182 \mu \mathrm{mol} / \mathrm{kg} /$ day reported no significant difference between peak manganese levels between groups [106]. However, peak levels in both groups were above normal ranges and there was no significant difference between groups in incidence of cholestasis or morbidity and mortality. Subgroup analysis raised the concern that infants on the higher dose for $>14$ days had an increased rate of cholestasis. Supplementation should be stopped in infants with cholestasis [94]. In infants receiving long-term $\mathrm{PN}$, a low dose supply of no more than $1 \mu \mathrm{g} / \mathrm{kg} /$ day $(0.0182 \mu \mathrm{mol} / \mathrm{kg} /$ day $)$ is recommended [10] (LOE II, GOR C).

Molybdenum: Deficiency has not been reported in newborns. Observational data led to the speculation that an intravenous intake of $1 \mu \mathrm{g} / \mathrm{kg} /$ day would be adequate for the LBW infant [107]. Intravenous molybdenum supply of $1 \mu \mathrm{g} / \mathrm{kg} /$ day $(0.01 \mu \mathrm{mol} / \mathrm{kg} /$ day $)$ is recommended for the LBW infant [10] (LOE III-3. GOR D).

There are 2 commercial trace element formulas available in Australia and neither of them has the right mix of trace elements for neonatal use. AUSPEN Neonatal Trace elements (Baxter Healthcare Pty Ltd) contains more copper and manganese but less zinc. Peditrace (Fresenius-Kabi Pty Ltd) contains fluorine. Consensus was to add zinc, selenium and iodine as individual trace elements to all AA/Dextrose formulations. Exception is the starter formulation to which trace elements could not be added due to physico-chemical compatibility concerns. For those infants, who are on exclusive PN for more than 2-4 weeks with minimal enteral intake, other trace elements (copper, manganese and molybdenum) can be added to the formulations.

\section{Duration of infusion}

Parenteral nutrition solution: In a randomised trial enrolling 166 infants, there is no significant difference in bacterial or fungal colonisation of infusate or neonatal sepsis in infants receiving 24 or 48 hour infusions of parenteral nutrition solution [108]. A before-after intervention study reported extending $\mathrm{PN}$ solution hang time from 24 to 48 hours did not alter central line associated blood stream infection rate and was associated with a reduced PNrelated cost and perceived nursing workload [109].

Lipid infusion: In previously mentioned randomised trial, fungal contamination may be increased in infants receiving lipid infusion for 24 hours compared to 48 hours [108]. In another trial randomising PN set changes (rather than infants), microbial contamination of infusion sets was significantly more frequent with 72-hour than with 24-hour set changes in neonates receiving lipid solutions [110].

\section{Physico-chemical stability}

Bouchoud and colleagues studied the long term physicochemical stability of the standardised AA/Dextrose and 
lipid emulsions [82]. The formulations tested were of similar concentrations to the ones we proposed in our consensus. Their AA/Dextrose solutions contain 3\% AA, $10.8 \%$ glucose and heparin $0.5 \mathrm{IU} / \mathrm{ml}$ and the lipid emulsion was lipofundin with vitamins added to it. AA/Dextrose was supplied in multilayered plastic bag and lipid emulsions were supplied in polypropelene syringes, similar to our practice. They demonstrated an optimal physical and chemical stability of AA/Dextrose solutions even if they are stored for a few weeks at room temperature. Similarly, lipid emulsions containing vitamins showed negligible difference in physical stability, lipid peroxide and vitamin levels when stored at room temperature for a few weeks.

The consensus recommended a hang time of 48 hours for PN solution and lipid (LOE II, GOR C).

\section{Discussion}

To our knowledge, this is the first consensus on the standardisation of parenteral nutrition across a majority of units. The main consensus achievement was to develop evidence based standardised formulations which can be implemented with minimal need for individualisation in the newborn population, and to provide framework for further development as new evidence becomes available. Success was facilitated by the majority NICUs participating in the consensus group already using standardised PN formulations. At the time of writing up this manuscript, 20 NICUs from Australia, New Zealand, Singapore and Malaysia are currently participating in the consensus group. NICUs in the group variably implemented some or all the formulations.

The consensus group negotiated a universal price for the whole Australia and fixed for 3 years. A common PN clinical protocol has been developed which is being implemented across many NICUs.

There are some limitations and gaps in the formulations and some unresolved issues in the initial consensus. Starter AA/dextrose formulation contain $33 \mathrm{~g} / \mathrm{L}$ of AA, which provides $2 \mathrm{~g} / \mathrm{kg} / \mathrm{d}$ of AA at $60 \mathrm{ml} / \mathrm{kg} / \mathrm{d}$. However, there are some extreme preterm infants who may be receiving other intravenous infusions which clinicians include in the total fluid intake resulting in a reduced calorie and AA intake. Pharmaceutical advice at the time of the consensus was not to exceed $33 \mathrm{~g} / \mathrm{L}$ of AA due to stability and compatibility concerns. There was consensus on the addition of zinc, selenium and iodine but we were unable to reach any consensus on the routine addition of other trace elements.

Currently, there is an observational study underway testing the safety and efficacy of the new consensus formulations. The findings of this study may help further improve these formulations.

\section{Conclusion}

In conclusion, consensus is achievable in standardising the $\mathrm{PN}$ formulations in the neonatal intensive care units. This has the potential to improve nutrient intakes, quality control, cost effectiveness and reduce prescription errors.

\section{Abbreviations \\ AA: Amino acids; ACT: Australian capital territory; ANZ: Australia and New Zealand; ESPGHAN: European society of paediatric gastroenterology, hepatology and nutrition; GOR: Grade of recommendation; LOE: Level of evidence; NICU: Neonatal intensive care unit; PN: Parenteral nutrition; RDI: Recommended daily intakes; VLBW: Very low birthweight.}

\section{Competing interests}

Authors have no competing (financial or non-financial) interests to declare.

\section{Authors' contribution}

SB was a core group member of the consensus group and conceptualized the consensus process and along with co-authors organised all the proceedings of the meetings, and drafted the initial manuscript. DO was a core group member of the consensus group, contributed to the concept and design of the consensus, and performed critical review of the level of evidence and grading of recommendation, JS was a core group member of the group, contributed to the concept and design of the consensus and contribution to the writings of all proceedings, KL was a core group member and contributed to the concept, design and networking for the consensus, reviewed and assisted in writing up manuscript. All authors approved the final manuscript as submitted.

\section{Members of the Consensus Group in alphabetical order}

Centenary Hospital, Canberra, Australia - Dr Alison Kent

Children's Hospital at Westmead, Australia -Dr Amit Trivedi, Ms Demiana Yaacoub

Flinders Medical Centre, Adelaide, Australia - Dr Scott Morris, Dr Peter Marshall

Gold Coast Hospital, Gold Coast, Australia - Dr Pita Birch

Hawkes Bay Hospital, Hastings, New Zealand - Dr Jenny Corban

Hospital Putrajaya, Malaysia - Dr Vidya Natthondan

Hospital Sg Buloh, Malaysia - Dr See Kwee Ching

John Hunter Children's Hospital, Newcastle, Australia - Dr Chris Wake KEM Hospital, Pune, India - Dr Umesh Vaidya

Liverpool Hospital, Liverpool, Australia - Dr Rodney Tobiansky, Ms Natalie Pazanin Monash Medical Centre, Melbourne, Australia - Dr Kenneth Tan

Nepean Hospital, Nepean, Australia - Dr Lyn Downe, Dr Girish Deshpande Royal North Shore Hospital, St Leonards, Australia - Dr John Sinn

Royal Prince Alfred Hospital, Camperdown, Australia - Dr David Osborn Royal Hobart Hospital, Hobart, Australia - Dr Tony De Paoli

Royal Hospital for Women, Randwick, Australia - Dr Srinivas Bolisetty, Assoc Prof Kei Lui

St John of God Hospital, Subiaco, Australia - Dr Joanne Colvin

Sydney Children's Hospital, Randwick, Australia - Dr Hari Ravindranathan, Dr Nitin Gupta, Mr Declan Gibney

Westmead Hospital, Westmead, Australia - Dr Melissa Luig, Mr Kingsley Ng, Ms Tamara Pham

Women's and Children's Hospital, Adelaide, Australia - Dr Andrew McPhee

\section{Author details}

'Division of Newborn Services, Royal Hospital for Women, Barker Street, Locked Bag 2000, Randwick, 2031 Sydney NSW, Australia. ${ }^{2}$ RPA Newborn Care, Royal Prince Alfred Hospital, Sydney, Australia. ${ }^{3}$ Department of Neonatology, Royal North Shore Hospital, Sydney, Australia. ${ }^{4}$ School of Women's and Children's Heath, University of New South Wales, Sydney, Australia. ${ }^{5}$ Sydney Medical School, University of Sydney, Sydney, Australia.

Received: 1 November 2013 Accepted: 13 February 2014 Published: 18 February 2014

\section{References}

1. Electronic correspondence with Baxter healthcare Pty limited. Sydney, Australia; 2009.

2. NHMRC Levels of Evidence and Grades for Recommendations for Developers of Guidelines. 2009. www.nhmrc.gov.au/publications/synopses/cp65syn.htm. 
3. Beecroft C, Martin H, Puntis JW: How often do parenteral nutrition prescriptions for the newborn need to be individualized? Clin Nutr 1999, 18:83-85.

4. lacobelli S, Bonsante F, Vintejoux A, Gouyon JB: Standardized parenteral nutrition in preterm infants: early impact on fluid and electrolyte balance. Neonatol 2010, 98:84-90.

5. Lenclen R, Crauste-Manciet S, Narcy P, Boukhouna S, Geffray A, Guerrault MN, Bordet F, Brossard D: Assessment of implementation of a standardized parenteral formulation for early nutritional support of very preterm infants. Eur J Pediatr 2006, 165:512-518.

6. Yeung MY, Smyth JP, Maheshwari R, Shah S: Evaluation of standardized versus individualized total parenteral nutrition regime for neonates less than 33 weeks gestation. J Paediatr Child Health 2003, 39:613-617.

7. Smolkin T, Diab G, Shohat I, Jubran H, Blazer S, Rozen GS, Makhoul IR: Standardized versus individualized parenteral nutrition in very low birth weight infants: a comparative study. Neonatology 2010, 98:170-178.

8. Bell EF, Acarregui MJ: Restricted versus liberal water intake for preventing morbidity and mortality in preterm infants. Cochrane Database Syst Rev 2008, 1:CD000503.

9. Pediatric Nutrition Handbook. 6th edition. Edited by Kleinman RE Washington, D.C: American Academy of Pediatrics; 2009.

10. Koletzko B, Goulet O, Hunt J, Krohn K, Shamir R: Guidelines on paediatric parenteral nutrition of the European society of paediatric gastroenterology, hepatology and nutrition (ESPGHAN) and the European society for clinical nutrition and metabolism (ESPEN), supported by the European society of paediatric research (ESPR). J Pediatr Gastroenterol Nutr 2005, 41(Suppl 2):S1-S87.

11. Ziegler EE, Carlson SJ: Early nutrition of very low birth weight infants. J Maternal-Fetal Neonatal Med 2009, 22:191-197.

12. Thureen PJ, Hay WW Jr: Intravenous nutrition and postnatal growth of the micropremie. Clin Perinatol 2000, 27:197-219.

13. Lloyd DA: Energy requirements of surgical newborn infants receiving parenteral nutrition. Nutrition 1998, 14:101-104.

14. Clark RH, Chace DH, Spitzer AR: Effects of two different doses of amino acid supplementation on growth and blood amino acid levels in premature neonates admitted to the neonatal intensive care unit: a randomized, controlled trial. Pediatrics 2007, 120:1286-1296.

15. Ibrahim HM, Jeroudi MA, Baier RJ, Dhanireddy R, Krouskop RW: Aggressive early total parental nutrition in low-birth-weight infants. J Perinato/ 2004 24:482-486.

16. Pappoe TA, Wu S-Y, Pyati S: A randomized controlled trial comparing an aggressive and a conventional parenteral nutrition regimen in very low birth weight infants. J Neonatal-Perinatal Med 2009, 2:149-156.

17. Heimler R, Bamberger JM, Sasidharan P: The effects of early parenteral amino acids on sick premature infants. Indian J Pediatr 2010, 77:1395-1399.

18. te Braake FW, van den Akker CH, Wattimena DJ, Huijmans JG, van Goudoever JB: Amino acid administration to premature infants directly after birth. J Pediatr 2005, 147:457-461.

19. Rivera A Jr, Bell EF, Bier DM: Effect of intravenous amino acids on protein metabolism of preterm infants during the first three days of life. Pediatr Res 1993, 33:106-111.

20. van den Akker $\mathrm{CH}$, te Braake FW, Schierbeek $\mathrm{H}$, Rietveld T, Wattimena DJ, Bunt JE, van Goudoever JB: Albumin synthesis in premature neonates is stimulated by parenterally administered amino acids during the first days of life. Am J Clin Nutr 2007, 86:1003-1008.

21. Van Goudoever JB, Colen T, Wattimena JL, Huijmans JG, Carnielli VP, Sauer $P J:$ Immediate commencement of amino acid supplementation in preterm infants: effect on serum amino acid concentrations and protein kinetics on the first day of life. J Pediatr 1995, 127:458-465.

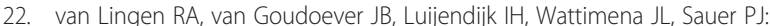
Effects of early amino acid administration during total parenteral nutrition on protein metabolism in pre-term infants. Clin Sci (Lond) 1992, 82:199-203.

23. Murdock N, Crighton A, Nelson LM, Forsyth JS: Low birthweight infants and total parenteral nutrition immediately after birth. II. Randomised study of biochemical tolerance of intravenous glucose, amino acids, and lipid. Arch Dis Child Fetal Neonatal Ed 1995, 73:F8-F12.

24. Wilson DC, Cairns P, Halliday HL, Reid M, McClure G, Dodge JA: Randomised controlled trial of an aggressive nutritional regimen in sick very low birthweight infants. Arch Dis Child Fetal Neonatal Ed 1997, 77:F4-F11.

25. Trivedi A, Sinn JK: Early versus late administration of amino acids in preterm infants receiving parenteral nutrition. Cochrane Database Syst Rev 2013, 7, CD008771.

26. Blanco CL, Falck A, Green BK, Cornell JE, Gong AK: Metabolic responses to early and high protein supplementation in a randomized trial evaluating the prevention of hyperkalemia in extremely low birth weight infants. J Pediatr 2008, 153:535-540.

27. Thureen PJ, Melara D, Fennessey PV, Hay WW Jr: Effect of low versus high intravenous amino acid intake on very low birth weight infants in the early neonatal period. Pediatr Res 2003, 53:24-32.

28. Can E, Bulbul A, Uslu S, Comert S, Bolat F, Nuhoglu A: Effects of aggressive parenteral nutrition on growth and clinical outcome in preterm infants. Pediatr Int 2012, 54:869-874.

29. Ridout E, Melara D, Rottinghaus S, Thureen PJ: Blood urea nitrogen concentration as a marker of amino-acid intolerance in neonates with birthweight less than $1250 \mathrm{~g}$. J Perinatol 2005, 25:130-133.

30. Usmani SS, Cavaliere T, Casatelli J, Harper RG: Plasma ammonia levels in very low birth weight preterm infants. J Pediatr 1993, 123:797-800.

31. ESPGHAN: ESPGHAN guidelines on paediatric parenteral nutrition. 5 Carbohydrates. J Pediatr Gastroenterol Nutr 2005, 41(Suppl 2):S28-S32.

32. Forsyth JS, Crighton A: Low birthweight infants and total parenteral nutrition immediately after birth. I. Energy expenditure and respiratory quotient of ventilated and non-ventilated infants. Arch Dis Child Fetal Neonatal Ed 1995, 73:F4-F7.

33. Lafeber HN, Sulkers EJ, Chapman TE, Sauer PJ: Glucose production and oxidation in preterm infants during total parenteral nutrition. Pediatr Res 1990, 28:153-157.

34. Jones MO, Pierro A, Hammond P, Nunn A, Lloyd DA: Glucose utilization in the surgical newborn infant receiving total parenteral nutrition. $J$ Pediatr Surg 1993, 28:1121-1125.

35. Nose O, Tipton JR, Ament ME, Yabuuchi H: Effect of the energy source on changes in energy expenditure, respiratory quotient, and nitrogen balance during total parenteral nutrition in children. Pediatr Res 1987, 21:538-541.

36. Hays SP, Smith EO, Sunehag AL: Hyperglycemia is a risk factor for early death and morbidity in extremely low birth-weight infants. Pediatrics 2006, 118:1811-1818.

37. Heimann K, Peschgens T, Kwiecien R, Stanzel S, Hoernchen H, Merz U: Are recurrent hyperglycemic episodes and median blood glucose level a prognostic factor for increased morbidity and mortality in premature infants $</=1500 \mathrm{~g}$ ? J Perinat Med 2007, 35:245-248.

38. Kao LS, Morris BH, Lally KP, Stewart CD, Huseby V, Kennedy KA: Hyperglycemia and morbidity and mortality in extremely low birth weight infants. J Perinatol 2006, 26:730-736.

39. Rowen $\mathrm{J}$, Atkins JT, Levy ML, Baer SC, Baker CJ: Invasive fungal dermatitis in the $<$ or $=1000$-gram neonate. Pediatrics 1995, 95:682-687.

40. Manzoni P, Castagnola E, Mostert M, Sala U, Galletto P, Gomirato G: Hyperglycaemia as a possible marker of invasive fungal infection in preterm neonates. Acta Paediatr 2006, 95:486-493.

41. Garg R, Agthe AG, Donohue PK, Lehmann CU: Hyperglycemia and retinopathy of prematurity in very low birth weight infants. J Perinato 2003, 23:186-194.

42. Blanco CL, Baillargeon JG, Morrison RL, Gong AK: Hyperglycemia in extremely low birth weight infants in a predominantly Hispanic population and related morbidities. J Perinatol 2006, 26:737-741.

43. Ertl T, Gyarmati J, Gaal V, Szabo I: Relationship between hyperglycemia and retinopathy of prematurity in very low birth weight infants. Biol Neonate 2006, 89:56-59.

44. Bottino M, Cowett RM, Sinclair JC: Interventions for treatment of neonatal hyperglycemia in very low birth weight infants. Cochrane Database Syst Rev 2009, 10:CD007453

45. Sinclair JC, Bottino M, Cowett RM: Interventions for prevention of neonatal hyperglycemia in very low birth weight infants. Cochrane Database Syst Rev 2009, 3:CD007615.

46. Gilbertson N, Kovar IZ, Cox DJ, Crowe L, Palmer NT: Introduction of intravenous lipid administration on the first day of life in the very low birth weight neonate. J Pediatr 1991, 119:615-623.

47. Beardsall K, Vanhaesebrouck S, Ogilvy-Stuart AL, Vanhole C, Palmer CR, van Weissenbruch M, Midgley P, Thompson M, Thio M, Cornette L, Ossuetta I, 
Iglesias I, Theyskens C, de Jong M, Ahluwalia JS, de Zegher F, Dunger DB: Early insulin therapy in very-low-birth-weight infants. New Eng J Med 2008, 359:1873-1884.

48. Collins JW Jr, Hoppe M, Brown K, Edidin DV, Padbury J, Ogata ES: A controlled trial of insulin infusion and parenteral nutrition in extremely low birth weight infants with glucose intolerance. J Pediatr 1991 , 118:921-927.

49. Meetze W, Bowsher R, Compton J, Moorehead H: Hyperglycemia in extremely- low-birth-weight infants. Biol Neonate 1998, 74:214-221.

50. Costarino AT Jr, Gruskay JA, Corcoran L, Polin RA, Baumgart S: Sodium restriction versus daily maintenance replacement in very low birth weight premature neonates: a randomized, blind therapeutic trial. J Pediatr 1992, 120:99-106.

51. Hartnoll G, Betremieux P, Modi N: Randomised controlled trial of postnatal sodium supplementation on oxygen dependency and body weight in 25-30 week gestational age infants. Arch Dis Child Fetal Neonatal Ed 2000, 82:F19-F23.

52. Shaffer SG, Meade VM: Sodium balance and extracellular volume regulation in very low birth weight infants. J Pediatr 1989, 115:285-290.

53. Hartnoll G, Betremieux P, Modi N: Randomised controlled trial of postnatal sodium supplementation in infants of 25-30 weeks gestational age: effects on cardiopulmonary adaptation. Arch Dis Child Fetal Neonatal Ed 2001, 85:F29-F32.

54. Vanpee $M$, Herin $P$, Broberger $U$, Aperia A: Sodium supplementation optimizes weight gain in preterm infants. Acta Paediatr 1995, 84:1312-1314

55. Vemgal $P$, Ohlsson A: Interventions for non-oliguric hyperkalaemia in preterm neonates. Cochrane Database Syst Rev 2012, 5, CD005257.

56. Schanler RJ, Shulman RJ, Prestridge LL: Parenteral nutrient needs of very low birth weight infants. J Pediatr 1994, 125:961-968.

57. Bonsante F, lacobelli S, Chantegret C, Martin D, Gouyon JB: The effect of parenteral nitrogen and energy intake on electrolyte balance in the preterm infant. Eur J Clin Nutr 2011, 65:1088-1093.

58. Peters O, Ryan S, Matthew L, Cheng K, Lunn J: Randomised controlled trial of acetate in preterm neonates receiving parenteral nutrition. Arch Dis Child Fetal Neonatal Ed 1997, 77:F12-F15.

59. Richards CE, Drayton M, Jenkins H, Peters TJ: Effect of different chloride infusion rates on plasma base excess during neonatal parenteral nutrition. Acta Paediatr 1993, 82:678-682.

60. Pereira-da-Silva L, Costa A, Pereira L, Filipe A, Virella D, Leal E, Moreira A, Rosa M, Mendes L, Serelha M: Early high calcium and phosphorus intake by parenteral nutrition prevents short-term bone strength decline in preterm infants. J Pediatr Gastroenterol Nutr 2011, 52:203-209.

61. Prestridge LL, Schanler RJ, Shulman RJ, Burns PA, Laine LL: Effect of parenteral calcium and phosphorus therapy on mineral retention and bone mineral content in very low birth weight infants. J Pediatr 1993, 122:761-768.

62. Pereira-da-Silva L, Nurmamodo A, Amaral JM, Rosa ML, Almeida MC, Ribeiro $\mathrm{ML}$ : Compatibility of calcium and phosphate in four parenteral nutrition solutions for preterm neonates. Am J Health-Syst Pharma 2003 60:1041-1044

63. Devlieger H, Meyers $Y$, Willems L, de Zegher F, Van Lierde S, Proesmans W, Eggermont E: Calcium and phosphorus retention in the preterm infant during total parenteral nutrition. A comparative randomised study between organic and inorganic phosphate as a source of phosphorus. Clin Nutr 1993, 12:277-281.

64. Koo WW, Tsang RC, Succop P, Krug-Wispe SK, Babcock D, Oestreich AE: Minimal vitamin $D$ and high calcium and phosphorus needs of preterm infants receiving parenteral nutrition. J Pediatr Gastroenterol Nutr 1989, 8:225-233.

65. Schanler RJ, Rifka M: Calcium, phosphorus and magnesium needs for the low-birth-weight infant. Acta Paediatr Supp/ 1994, 405:111-116.

66. Shah PS, Shah VS: Continuous heparin infusion to prevent thrombosis and catheter occlusion in neonates with peripherally placed percutaneous central venous catheters. Cochrane Database Syst Rev 2008 , 2:CD002772

67. Simmer K, Rao SC: Early introduction of lipids to parenterally-fed preterm infants. Cochrane Database Syst Rev 2005, 2:CD005256.

68. Vlaardingerbroek $\mathrm{H}$, Veldhorst MA, Spronk S, van den Akker $\mathrm{CH}$, van Goudoever JB: Parenteral lipid administration to very-low-birth-weight infants-early introduction of lipids and use of new lipid emulsions: a systematic review and meta-analysis. Am J Clin Nutr 2012, 96:255-268.

69. Demirel G, Oguz SS, Celik IH, Erdeve O, Uras N, Dilmen U: The metabolic effects of two different lipid emulsions used in parenterally fed premature infants-a randomized comparative study. Early Hum Dev 2012, 88:499-501.

70. Deshpande GC, Simmer K, Mori T, Croft K: Parenteral lipid emulsions based on olive oil compared with soybean oil in preterm ( $<28$ weeks' gestation) neonates: a randomised controlled trial. J Pediatr Gastroenterol Nutr 2009, 49:619-625.

71. Gawecka A, Michalkiewicz J, Kornacka MK, Luckiewicz B, Kubiszewska I: Immunologic properties differ in preterm infants fed olive oil vs soy-based lipid emulsions during parenteral nutrition. J Parenter Enteral Nutr 2008, 32:448-453.

72. Gobel Y, Koletzko B, Bohles HJ, Engelsberger I, Forget D, Le Brun A, Peters J, Zimmermann A: Parenteral fat emulsions based on olive and soybean oils: a randomized clinical trial in preterm infants. J Pediatr Gastroenterol Nutr 2003, 37:161-167.

73. Koksal N, Kavurt AV, Cetinkaya M, Ozarda Y, Ozkan H: Comparison of lipid emulsions on antioxidant capacity in preterm infants receiving parenteral nutrition. Pediatr Int 2011, 53:562-566.

74. Rayyan M, Devlieger H, Jochum F, Allegaert K: Short-term use of parenteral nutrition with a lipid emulsion containing a mixture of soybean oil, olive oil, medium-chain triglycerides, and fish oil: a randomized double-blind study in preterm infants. J Parenter Enteral Nutr 2012, 36:81S-94S.

75. Roggero P, Mosca F, Gianni ML, Orsi A, Amato O, Migliorisi E, Longini M, Buonocore G: F2-isoprostanes and total radical-trapping antioxidant potential in preterm infants receiving parenteral lipid emulsions. Nutrition 2010, 26:551-555.

76. Savini S, D’Ascenzo R, Biagetti C, Serpentini G, Pompilio A, Bartoli A, Cogo $P E$, Carnielli VP: The effect of 5 intravenous lipid emulsions on plasma phytosterols in preterm infants receiving parenteral nutrition: a randomized clinical trial. Am J Clin Nutr 2013, 98:312-318.

77. Skouroliakou M, Konstantinou D, Koutri K, Kakavelaki C, Stathopoulou M, Antoniadi M, Xemelidis N, Kona V, Markantonis S: A double-blind, randomized clinical trial of the effect of omega- 3 fatty acids on the oxidative stress of preterm neonates fed through parenteral nutrition. Eur J Clin Nutr 2010, 64:940-947.

78. Tomsits E, Pataki M, Tolgyesi A, Fekete G, Rischak K, Szollar L: Safety and efficacy of a lipid emulsion containing a mixture of soybean oil, medium-chain triglycerides, olive oil, and fish oil: a randomised, doubleblind clinical trial in premature infants requiring parenteral nutrition. J Pediatr Gastroenterol Nutr 2010, 51:514-521.

79. Webb AN, Hardy P, Peterkin M, Lee O, Shalley H, Croft KD, Mori TA, Heine RG, Bines JE: Tolerability and safety of olive oil-based lipid emulsion in critically ill neonates: a blinded randomized trial. Nutrition 2008, 24:1057-1064

80. Deshpande G, Simmer K, Deshmukh M, Mori TA, Croft KD, Kristensen J: Fish Oil (SMOFlipid) and Olive Oil Lipid (Clinoleic) in Very Preterm Neonates. J Pediatr Gastroenterol Nutr 2014, 58:179-184.

81. Miloudi K, Comte B, Rouleau T, Montoudis A, Levy E, Lavoie JC: The mode of administration of total parenteral nutrition and nature of lipid content influence the generation of peroxides and aldehydes. Clin Nutr 2012, 31:526-534.

82. Bouchoud L, Sadeghipour F, Klingmuller M, Fonzo-Christe C, Bonnabry P: Long-term physico-chemical stability of standard parenteral nutritions for neonates. Clin Nutr 2010, 29:808-812.

83. Silvers KM, Sluis KB, Darlow BA, McGill F, Stocker R, Winterbourn CC: Limiting light-induced lipid peroxidation and vitamin loss in infant parenteral nutrition by adding multivitamin preparations to Intralipid. Acta Paediatr 2001, 90:242-249.

84. Grand A, Jalabert A, Mercier G, Florent M, Hansel-Esteller S, Cambonie G, Steghens JP, Picaud JC: Influence of vitamins, trace elements, and iron on lipid peroxidation reactions in all-in-one admixtures for neonatal parenteral nutrition. J Parenter Enteral Nutr 2011, 35:505-510.

85. Bassiouny MR, Almarsafawy $\mathrm{H}$, Abdel-Hady $\mathrm{H}$, Nasef N, Hammad TA, Aly H: A randomized controlled trial on parenteral nutrition, oxidative stress, and chronic lung diseases in preterm infants. J Pediatr Gastroenterol Nutr 2009, 48:363-369.

86. Levy R, Herzberg GR, Andrews WL, Sutradhar B, Friel JK: Thiamine, riboflavin, folate, and vitamin B12 status of low birth weight infants 
receiving parenteral and enteral nutrition. J Parenter Enteral Nutr 1992, 16:241-247.

87. Porcelli PJ, Greene $H$, Adcock E: A modified vitamin regimen for vitamin B2, A, and E administration in very-low-birth-weight infants. J Pediatr Gastroenterol Nutr 2004, 38:392-400.

88. Friel JK, Bessie JC, Belkhode SL, Edgecombe C, Steele-Rodway M, Downton $G$, Kwa PG, Aziz K: Thiamine, riboflavin, pyridoxine, and vitamin $C$ status in premature infants receiving parenteral and enteral nutrition. J Pediatr Gastroenterol Nutr 2001, 33:64-69.

89. Darlow BA, Graham PJ: Vitamin A supplementation to prevent mortality and short- and long-term morbidity in very low birthweight infants. Cochrane Database Syst Rev 2011:CD000501.

90. Darlow BA, Buss H, McGill F, Fletcher L, Graham P, Winterbourn CC: Vitamin $C$ supplementation in very preterm infants: a randomised controlled trial. Arch Dis Child Fetal Neonatal Ed 2005, 90:F117-F122.

91. Greene HL, Moore ME, Phillips B, Franck L, Shulman RJ, Ament ME, Murrell JE, Chan MM, Said HM: Evaluation of a pediatric multiple vitamin preparation for total parenteral nutrition. II. Blood levels of vitamins A, D, and E. Pediatrics 1986, 77:539-547.

92. Brion LP, Bell EF, Raghuveer TS: Vitamin E supplementation for prevention of morbidity and mortality in preterm infants. Cochrane Database Syst Rev 2003:CD003665.

93. Kumar D, Greer FR, Super DM, Suttie JW, Moore JJ: Vitamin K status of premature infants: implications for current recommendations. Pediatrics 2001, 108:1117-1122.

94. Burjonrappa SC, Miller M: Role of trace elements in parenteral nutrition support of the surgical neonate. J Pediatr Surg 2012, 47:760-771.

95. Darlow BA, Austin NC: Selenium supplementation to prevent short-term morbidity in preterm neonates. Cochrane Database Syst Rev 2003:CD003312.

96. Ibrahim M, Sinn J, McGuire W: lodine supplementation for the prevention of mortality and adverse neurodevelopmental outcomes in preterm infants. Cochrane Database Syst Rev 2006, 2:CD005253.

97. Ibrahim M, de Escobar GM, Visser TJ, Duran S, van Toor H, Strachan J, Williams FL, Hume R: lodine deficiency associated with parenteral nutrition in extreme preterm infants. Arch Dis Child Fetal Neonatal Ed 2003, 88:F56-F57.

98. Bona G, Chiorboli E, Rapa A, Weber G, Vigone MC, Chiumello G: Measurement of urinary iodine excretion to reveal iodine excess in neonatal transient hypothyroidism. J Pediatr Endocrinol Metab 1998, 11:739-743.

99. Moukarzel AA, Song MK, Buchman AL, Vargas J, Guss W, McDiarmid S, Reyen L, Ament ME: Excessive chromium intake in children receiving total parenteral nutrition. Lancet 1992, 339:385-388.

100. Nur M, Moukarzel A, Al-Rachach L, McCullagh A, Joseph L, Mehta R, Bainbridge $R$, Varada K, Mimouni F: Parenteral chromium toxicity in newborns receiving parenteral nutrition (Abstract). J Pediatr Gastroenterol Nutr 1996, 23:356.

101. Lockitch G, Pendray MR, Godolphin WJ, Quigley G: Serial changes in selected serum constituents in low birth weight infants on peripheral parenteral nutrition with different zinc and copper supplements. Am J Clin Nutr 1985, 42:24-30.

102. Lockitch G, Godolphin W, Pendray MR, Riddell D, Quigley G: Serum zinc, copper, retinol-binding protein, prealbumin, and ceruloplasmin concentrations in infants receiving intravenous zinc and copper supplementation. J Pediatr 1983, 102:304-308.

103. Zlotkin SH, Buchanan BE: Meeting zinc and copper intake requirements in the parenterally fed preterm and full-term infant. J Pediatr 1983 103:441-446.

104. Agostoni C, Buonocore G, Carnielli VP, De Curtis M, Darmaun D, Decsi T, Domellof M, Embleton ND, Fusch C, Genzel-Boroviczeny O, Goulet O, Kalhan SC, Kolacek S, Koletzko B, Lapillonne A, Mihatsch W, Moreno L, Neu J, Poindexter B, Puntis J, Putet G, Rigo J, Riskin A, Salle B, Sauer P, Shamir R, Szajewska H, Thureen P, Turck D, van Goudoever JB, Ziegler EE: Enteral nutrient supply for preterm infants: commentary from the European Society of Paediatric Gastroenterology, Hepatology and Nutrition Committee on Nutrition. J Pediatr Gastroenterol Nutr 2010, 50:85-91.

105. Rogahn J, Ryan S, Wells J, Fraser B, Squire C, Wild N, Hughes A, Amegavie L: Randomised trial of iodine intake and thyroid status in preterm infants. Arch Dis Child Fetal Neonatal Ed 2000, 83:F86-F90.
106. Fok TF, Chui KK, Cheung R, Ng PC, Cheung KL, Hjelm M: Manganese intake and cholestatic jaundice in neonates receiving parenteral nutrition: a randomized controlled study. Acta Paediatr 2001, 90:1009-1015.

107. Friel JK, MacDonald AC, Mercer CN, Belkhode SL, Downton G, Kwa PG, Aziz K, Andrews WL: Molybdenum requirements in low-birth-weight infants receiving parenteral and enteral nutrition. J Parenter Enteral Nutr 1999, 23:155-159.

108. Fox M, Molesky M, Van Aerde JE, Muttitt S: Changing parenteral nutrition administration sets every $24 \mathrm{~h}$ versus every $48 \mathrm{~h}$ in newborn infants. Canad J Gastroenterol 1999, 13:147-151.

109. Balegar VK, Azeem MI, Spence K, Badawi N: Extending total parenteral nutrition hang time in the neonatal intensive care unit: is it safe and cost effective? J Paediatr Child Health 2013, 49:E57-E61.

110. Matlow AG, Kitai I, Kirpalani H, Chapman NH, Corey M, Perlman M, Pencharz P, Jewell S, Phillips-Gordon C, Summerbell R, Ford-Jones EL: A randomized trial of 72- versus 24-hour intravenous tubing set changes in newborns receiving lipid therapy. Infect Control Hosp Epidemiol 1999, 20:487-493.

doi:10.1186/1471-2431-14-48

Cite this article as: Bolisetty et al.: Standardised neonatal parenteral nutrition formulations - an Australasian group consensus 2012. BMC Pediatrics 2014 14:48

\section{Submit your next manuscript to BioMed Central and take full advantage of:}

- Convenient online submission

- Thorough peer review

- No space constraints or color figure charges

- Immediate publication on acceptance

- Inclusion in PubMed, CAS, Scopus and Google Scholar

- Research which is freely available for redistribution 